\title{
Maritime and coastal spatial planning: the case of Greece and the Mediterranean
}

\author{
E. Beriatos \& M. Papageorgiou \\ Department of Planning and Regional Development, \\ University of Thessaly, Greece
}

\begin{abstract}
Maritime and coastal areas play an important role in the development of human activities and are a substantial influence on the economies of their respective hinterlands. Seas and coasts are among the most complex, vulnerable and sensitive to all natural ecosystems, and their management presents various problems and difficulties especially in our era of climate change in which coastal cities and populations face a range of serious threats (including rising sea levels). The singularity of these areas necessitates an equally singular handling of the issues of their land development and management.

At the start of the 21 st century the critical issue of the spatial regulation and organization of the seas and coasts is a key priority for Greece and the Mediterranean in the era of climate change. There can be no doubt that the Mediterranean's coastal and marine areas are facing ever greater risks from natural disasters and human pressures alike.

Given the experience of EU and UN programs and projects initiated and run by other international organizations which have shown that implementing sustainable spatial development in the coasts and seas is anything but easy, there is clearly a great need for coordinated action and co-operation at the transnational and international level. During the past decade the EU has adopted a strategy for the maritime environment which was incorporated in an Integrated Maritime Policy (IMP) (a European vision for the seas and the oceans). In the framework of the above policy the Commission launched in 2008 a road map for the Maritime Spatial Planning (MSP) as the basic means for the implementation of the (IMP) and a fundamental tool for the sustainable development of the European seas and coasts.
\end{abstract}


The paper aims to investigate the effectiveness of the planning instruments and policies launched by the EU in relation to maritime and coastal areas and adopted by the competent public agencies and bodies in Greece and Mediterranean. Furthermore, the paper argues for the substantial implementation of the policy documents relating to Integrated Coastal Zone Management (ICZM) and the Spatial Maritime Planning in the framework of EU strategy for the Integrated Maritime Policy.

\section{Introduction: the pressures on the Mediterranean coasts and the need for the integrated planning in the $21^{\text {st }}$ century}

At the start of the 21st century, the critical issue of the spatial regulation and organization of coastal and marine areas is a key priority for Europe, the Mediterranean and Greece in an era of climate change and environmental shifts. There can be no doubt that the Mediterranean's coastal and marine areas are facing ever greater risks from natural disasters and human pressures alike. The coastal environment is under serious threat from activities (like tourism, transportation etc.) carried out without recourse to even the must rudimentary principles of sustainability; as a result, developmentally and environmentally, these activities are anything but beneficial. Marine transportation and coastal and marine tourism constitute sources and focal points for pollution on land and at sea, and lead to the degradation of the marine and coastal ecosystems. Moreover, the building up (legally or illegally) of the coastal zone, especially near or on the foreshore and seashore, exacerbates the downgrading of these areas, which are also core tourism assets.

It should be noted that while the Mediterranean's coastal zones account for just $12 \%$ of the surface area of the nation-states bordering the Mediterranean, they are home to $33 \%$ of their populations. In addition, while the Mediterranean accounts for $7 \%$ of the world's population, the tourists who chose to holiday there account for roughly 33\% of the world's tourists! [1]. Construction pressures stemming from tourism are expected to lead to an increase in both the permanent population of the Mediterranean and in visitor numbers, which are forecast to rise from 200 million in 2008 to 300 million in 2025, a leap of 50\% [2]. It should also be noted that there is significant differentiation in both the quantitative (absolute number) and qualitative (country of origin) composition of the international tourists visiting the European and African/Asian Mediterranean.

A parallel reading of Figures 2 and 3 reveals that the urban population of the nations of the south-western Mediterranean is increasing at a rapid rate.

Thus, while there were ten metropolises (meaning cities with over a million inhabitants) in 1950, there were no fewer than 29 by the end of the century (1995). This leap in urbanization has led to more and larger metropolises, and thus, also, to the erection of a cement wall along the entire length of the Mediterranean coast, thanks to the construction of a mass of hotel and tourist complexes (Egypt, Turkey, Spain) as well as linear coastal settlements of 


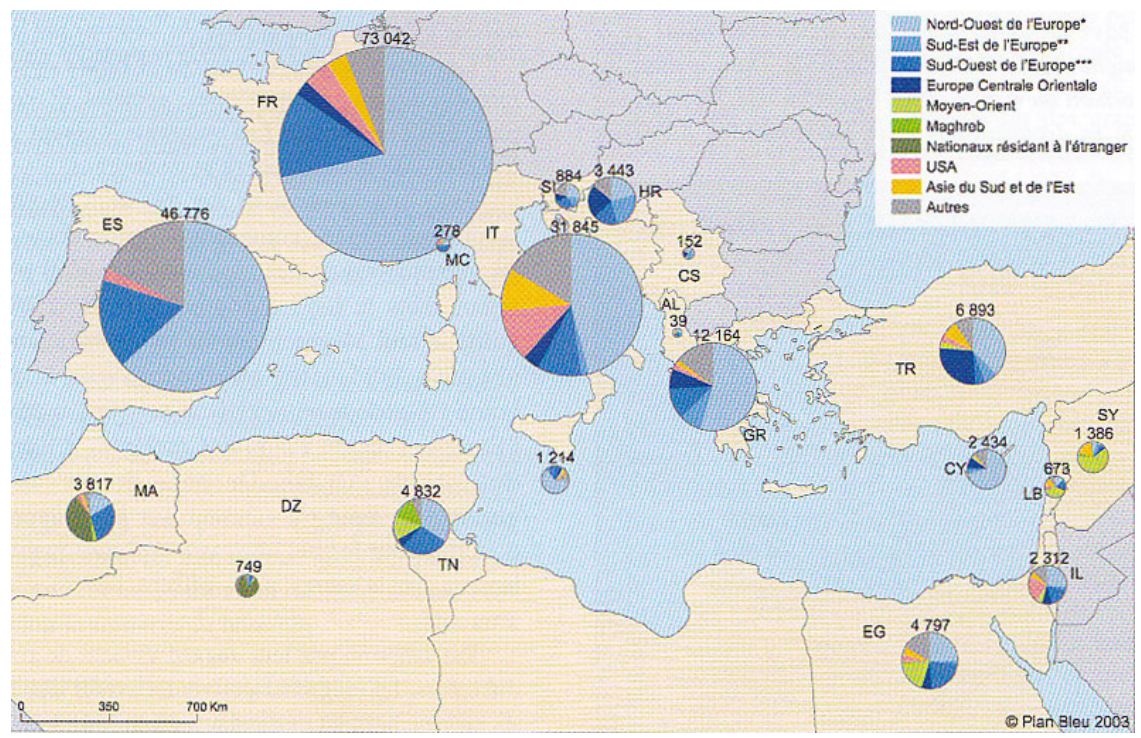

Figure 1: Number (in thousands) and origin of international tourists in Mediterranean countries in 1999. Source: [3].

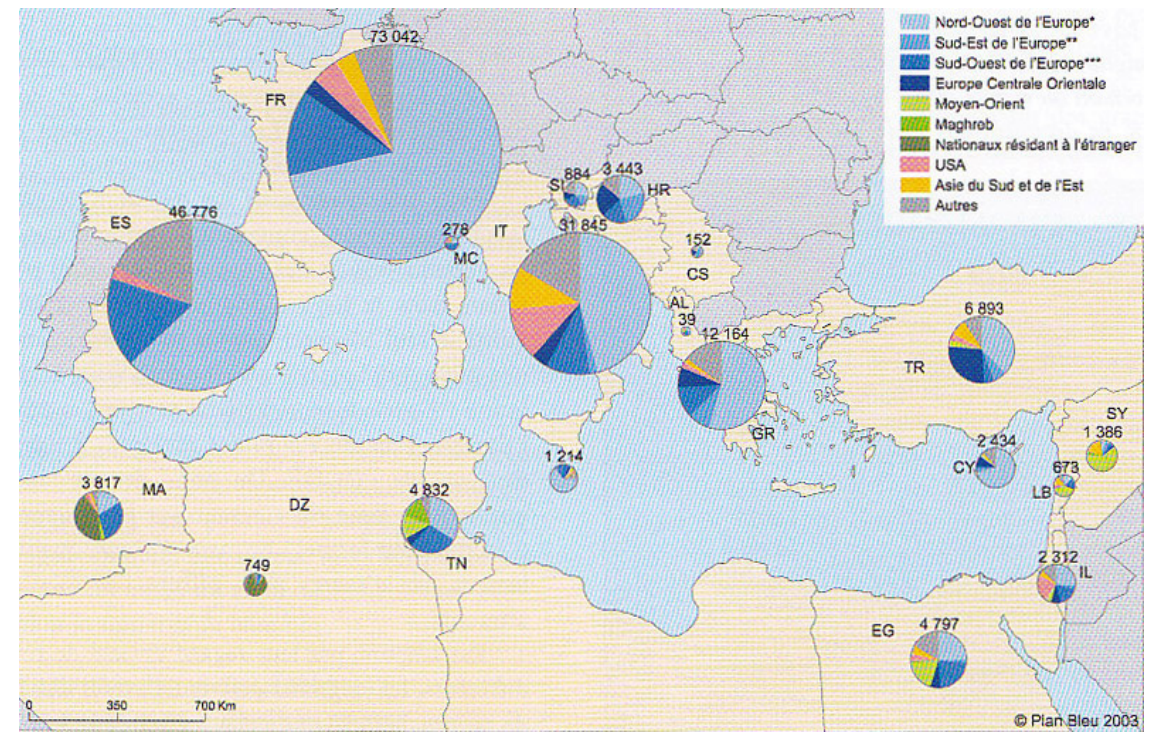

Figure 2: Urbanization rates in Mediterranean countries: 1950, 2000, 2030. Source: [3]. 

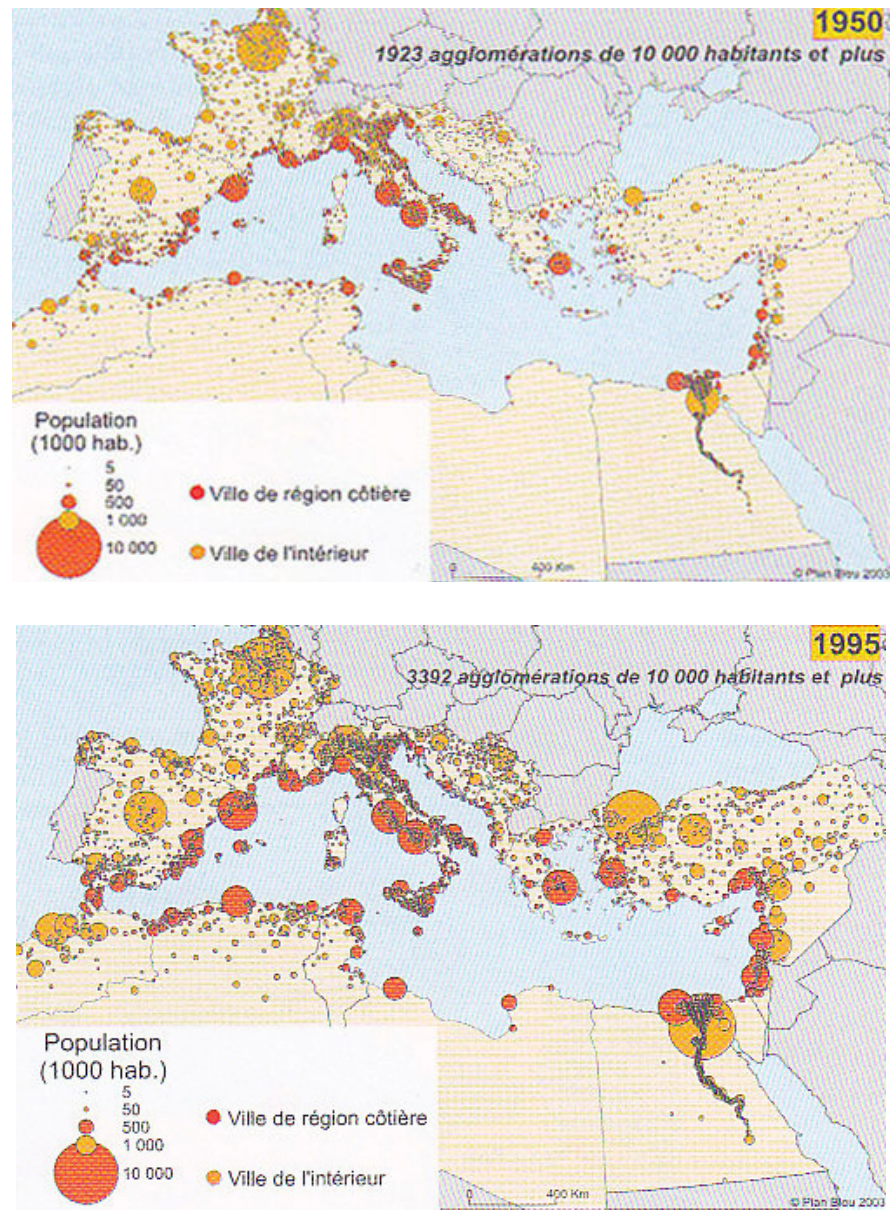

Figure 3: Cities and towns with more than 10,000 inhabitants: 1950-1995. Source: [3].

second-homes constructed legally or illegally (Greece, Spain). This wall tends to create a zone between the coastal highway and the coastline itself. Areas whose coastal development mirrors this pattern include Alexandria and El Alamein in Egypt, the area east of Antalya in Turkey, the coast beside Malaga and north of Valencia in Spain and the west coast of the Peloponnese in Greece (see Figures 4, 5, 6 and 7).

Similarly, the Blue Plan data points to the agricultural population having remained stable or declined as a result of tourist development in every Mediterranean coastal nation, in the developed north-west and less developed south-east alike [3]. The situation described above - and coastal urbanization and linear development, in particular - creates serious environmental problems as well as raising the cost of the necessary infrastructure. Integrated planning for the coastal and adjoining marine zones is thus essential. 


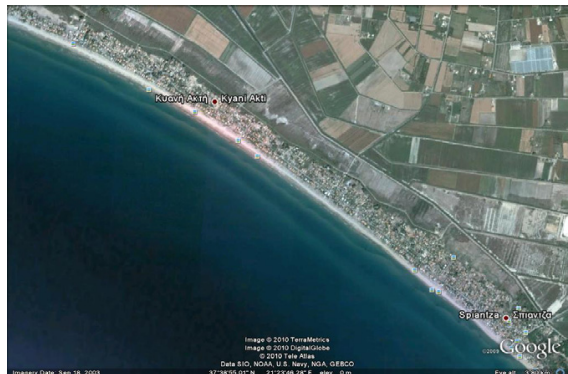

Figure 4: Western Peloponnese Greece.

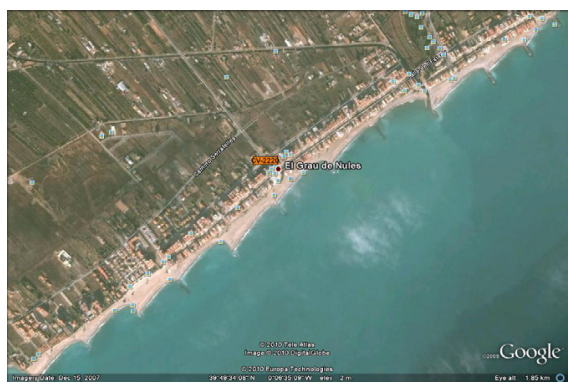

Figure 6: Valencia, Spain.

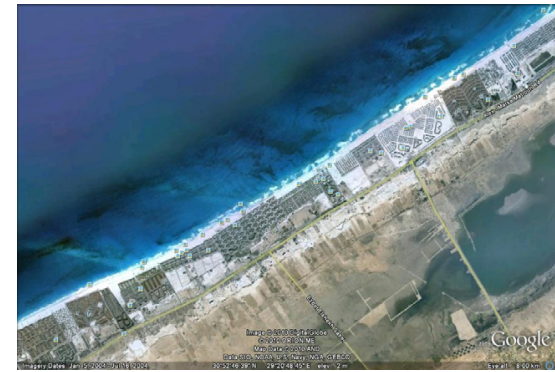

Figure 5: Alexandria-El Alamein, Egypt.

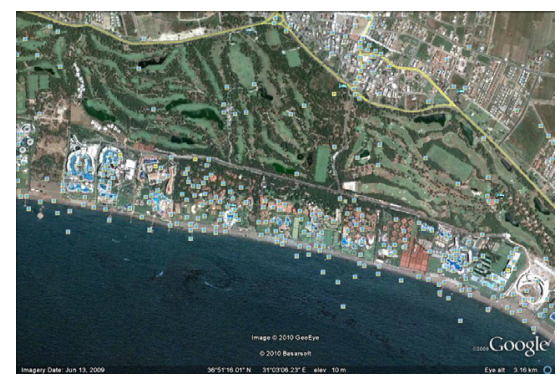

Figure 7: $\quad$ Turkey, Antalya.

\section{International policy for costs relating to the Euro-Mediterranean region}

Mediterranean coastal policy essentially began in 1975 when the Mediterranean Action Plan (MAP) was set up in Barcelona in the context of the United Nations Environment Programme (UNEP). The MAP, the first scheme of its kind, was set in motion by the UN to protect the planet's regional seas. Structurally, it is comprised of a coordinating unit, which has had its headquarters in Athens since 1982, plus six Regional Activity Centres based in six Mediterranean cities (Split, Palermo, Sophia Antipolis, Barcelona, Malta and Tunis) which occupy themselves with a range of issues and programmes, the most important of which are:

a) The Blue Plan / Plan Bleu based in Sophia Antipolis, which seeks to analyse environmental problems and achieve viable Mediterranean development by means of an interdisciplinary systemic approach, and b) the Priority Actions Program / Programme d'Actions Prioritaires, which is based in Split and focuses on the integrated coastal zone management with an emphasis on solving the problems created by the increasing urbanization of the Mediterranean coast.

It was within the MAP framework that the Barcelona Convention was signed in 1976 by the representatives of the Mediterranean's coastal states in Barcelona. 
Originally entitled the "Convention for the Protection of the Mediterranean Sea Against Pollution", the convention came into force in 1978; amended in 1995, it came into force in 2004 as the "Convention for the Protection of the Marine Environment and the Coastal Region of the Mediterranean". It should be noted that a number of sub-regional conventions were signed as a direct result of the Barcelona Convention, and numerous international committees formed with members drawn from neighbouring coastal states and a view to protecting the Mediterranean coast.

One of the Barcelona Convention's core functions is the publication of technical protocols on a series of crucial environmental issues (Table 1). One of the recent protocols, the supremely important Integrated Coastal Zone Management (ICZM) protocol, was signed in Madrid in 2008. Although the protocol represents a compromise between the conflicting interests of the states involved, it still constitutes an important legal obligation to protect the Mediterranean coast, and is a realistic document drawn up by a team including representatives of accredited NGOs which takes international experience into account. However, it has been ratified by just three states to date: France, Albania and Slovenia. Innovative and ground-breaking, the protocol is a unique

Table 1: $\quad$ Protocols of the Barcelona Convention.

\begin{tabular}{|c|c|}
\hline Date (adoption/entry into force) & Content \\
\hline $16-02-1976 / 12-02-1978$ & Dumping Protocol (from ships and aircraft) \\
\hline $16-02-1976 / 12-02-1978$ & $\begin{array}{l}\text { Prevention and Emergency Protocol (pollution from } \\
\text { ships and emergency situations) }\end{array}$ \\
\hline $17-05-1980 / 17-06-1983$ & Land-based Sources and Activities Protocol \\
\hline $10-06-1982 / 23-03-1986$ & $\begin{array}{l}\text { Protocol concerning Mediterranean Specially } \\
\text { Protected Areas }\end{array}$ \\
\hline 14-10-1994/Not yet & $\begin{array}{c}\text { Offshore Protocol (pollution from exploration and } \\
\text { exploitation) }\end{array}$ \\
\hline 10-06-1995/ Not yet & $\begin{array}{l}\text { Dumping Protocol (from ships and aircraft or incineration } \\
\text { at sea) (amended the Dumping Protocol of 1976) }\end{array}$ \\
\hline $10-06-1995 / 12-12-1999$ & $\begin{array}{l}\text { Protocol Concerning Specially Protected Areas in the } \\
\text { Mediterranean (replaced the Protocol concerning } \\
\text { Mediterranean Specially Protected Areas) }\end{array}$ \\
\hline $10-06-1995 / 12-12-1999$ & $\begin{array}{l}\text { Replaces the Protocol concerning } \\
\text { Mediterranean Specially Protected Areas of } 1982 \\
\end{array}$ \\
\hline 07-03-1996/11-05-2008 & $\begin{array}{l}\text { Protocol for the Protection of the Mediterranean Sea against } \\
\text { Pollution from Land-Based Sources (replaced the Land- } \\
\text { based Sources and Activities Protocol of 1980) }\end{array}$ \\
\hline 01-10-1996/18-01-2008 & Hazardous Wastes Protocol \\
\hline $25-01-2002 / 17-03-2004$ & $\begin{array}{l}\text { Protocol Concerning Cooperation in Preventing Pollution } \\
\text { from Ships and, in Cases of Emergency, Combating } \\
\text { Pollution of the Mediterranean Sea (replaced the Prevention } \\
\text { and Emergency Protocol of 1976) }\end{array}$ \\
\hline 21-01-2008/ Not yet & Protocol on Integrated Coastal Zone Management (ICZM) \\
\hline
\end{tabular}

Source: Relevant Official texts of Barcelona Convention protocols. 
legal instrument on ICZM in the entire international community in the context of the Coastal Area Management Programme (CAMP) and is unprecedented on a regional level [4].

Turning to its content, it is interesting to note that the protocol adopts inter alia the spatial - organic ecosystems - approach, the principle of the non edificandi zone and interdisciplinary analysis. We are of the opinion that the protocol would be hard to implement, and that the use of national spatial planning instruments (see section 4) is therefore essential to enable problems to be dealt with and solved, including the need for bodies and measures to be coordinated, for control mechanisms to be introduced with regard to the implementation of the legislation, for land policy to adopt mechanisms for the acquisition, of land to the public domain, and for measures to be taken in the light of climate change. The Coastal Area Management Programmes / Programme Activity Centres (CAMP-PAC) set up in many countries are one of the fundamental means of implementation for the ICZM protocol [5]. Figure 8 shows the areas where these programmes have been run or are currently running.

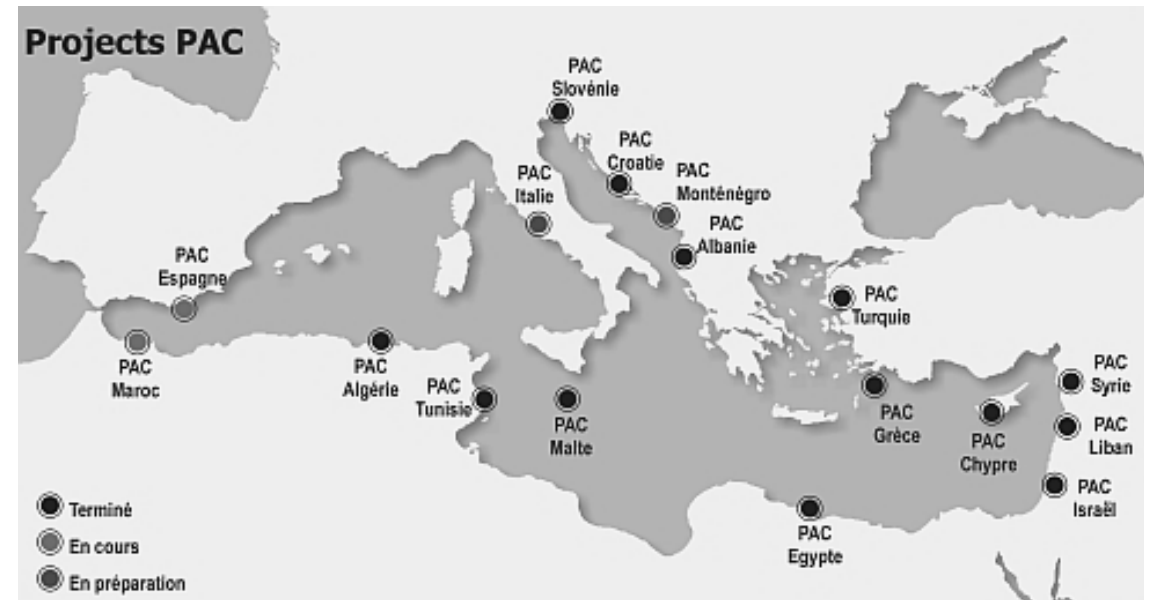

Figure 8: Coastal Area Management Programmes in specific Mediterranean regions. Source: [5].

Various noteworthy examples of policies and instruments on the national level should also be noted, including the Conservatoire de 1' Espace Littoral et des Rivages Lacustres (CELRL), a French national protection body for coastal spaces, lakes and rivers set up with a view to acquiring land from the public sector [6].

In parallel and in combination with the activities of the UN and the Barcelona Convention, the EU has undertaken initiatives relating to Integrated Coastal Zone Management in all its member-states. Thus, a pilot programme was set in motion in the late 1990s (1997-1999) whose conclusions led to the submission of a Proposal for a Recommendation [7] and the issuing of a Communication [8] to 
the Council and the European Parliament, which made a Recommendation on $30 / 05 / 2002$ relating to the implementation in Europe of the ICZM [9]. The Recommendation refers to the need for a strategic approach, the application of core management principles, national strategies and cooperation. In 2007, the Commission published a Communication [10] in the form of a report to the Council and the European Parliament evaluating the ICZM Recommendation in the light of previous evaluations (by the European Environment Agency (EEA) the indicators working group etc.).

This document also refers to the reports produced by 14 of the EU's 20 coastal member-states - Greece among them - which had been presented to the Commission. The evaluation revealed that, despite the positive impact made by the Recommendation through its championing of a "more holistic spatial planning", there had been delays and no significant progress. The national reports provided only limited information on the effectiveness of implementation mechanisms, while few countries and regions had contributed to the analysis of the environmental indictors. Moreover, the evaluation report recognized that the environmental degrading of the coasts remained a serious problem, and linked future progress in relation to ICZM with: a) the Green Paper on maritime policy, b) the ICZM protocol within the framework of the Barcelona Convention and c) the INSPIRE directive (2007/2 EU L108) which aims at a combined environmental information system (relevant policy documents in Table 2).

Table 2: Coastal and maritime spatial planning in Europe: Policy documents.

\begin{tabular}{|c|c|c|}
\hline Date & Content & Form \\
\hline 1999 & $\begin{array}{c}\text { Towards a European (ICZM) Strategy General Principles } \\
\text { and Policy Options }\end{array}$ & Reflection paper \\
\hline 08-09-2000 & $\begin{array}{c}\text { Implementation of Integrated Coastal Zone Management } \\
\text { in Europe }\end{array}$ & $\begin{array}{c}\text { Proposal for } \\
\text { Recommendation }\end{array}$ \\
\hline $27-09-2000$ & $\begin{array}{c}\text { On Integrated Coastal Zone Management: A strategy for } \\
\text { Europe }\end{array}$ & Communication \\
\hline $06-06-2002$ & $\begin{array}{c}\text { Implementation of the Integrated Coastal Zone } \\
\text { Management }\end{array}$ & Recommendation \\
\hline $07-06-2006$ & $\begin{array}{l}\text { Towards a future Maritime Policy for the Union: A } \\
\text { European vision for the oceans and seas }\end{array}$ & $\begin{array}{l}\text { Communication } \\
\text { /Green Paper }\end{array}$ \\
\hline $07-06-2007$ & $\begin{array}{l}\text { An evaluation of Integrated Coastal Zone Management } \\
\text { (ICZM) in Europe }\end{array}$ & Communication \\
\hline $10-10-2007$ & An Integrated Maritime Policy for the European Union & $\begin{array}{l}\text { Communication/Blue } \\
\text { Paper }\end{array}$ \\
\hline $25-06-2008$ & $\begin{array}{l}\text { Establishing a framework for community action in the } \\
\text { field of marine environmental policy (Marine Strategy } \\
\text { Framework Directive) }\end{array}$ & Directive \\
\hline $25-11-2008$ & $\begin{array}{c}\text { Roadmap for Maritime Spatial Planning: Achieving } \\
\text { Common Principles in the EU }\end{array}$ & Communication \\
\hline $26-06-2008$ & $\begin{array}{l}\text { Guidelines for an Integrated Approach to Maritime } \\
\text { Policy: Towards best practice in integrated maritime } \\
\text { governance and stakeholder consultation }\end{array}$ & Communication \\
\hline $15-10-2009$ & Progress Report on the EU's integrated maritime policy & Communication \\
\hline
\end{tabular}

Source: Relevant EU Official texts. 


\section{The case of coastal Greece: a critical approach to the existing situation and spatial planning}

In formal, official terms, Greece, an EU member-state, is considered a developed nation in accordance with every UN human development index. In essence, however, Greece is geographically part of the Balkans, south-eastern Europe and the Mediterranean, with all that entails in terms of influences from neighbouring states. Due to its geopolitical position, but also to its domestic policies and cultural and social traditions, Greece has problems which relate to its political system, its productive infrastructure, its administrative organization, to the development or research and technology and - above all - to the organization and planning of its space: urban, rural and special categories like coastal space.

That Greece has more coastline than any other European or Mediterranean country is a fundamental consideration in its spatial planning as well as its environmental and developmental policies. In fact, Greece has over 3000 islands and islets which represent $20 \%$ of its surface area and $14 \%$ of its population. In Greece, with over $15,000 \mathrm{~km}$ of coastline, every square kilometre equates to 114 $\mathrm{m}$ of coast or "sea front", compared to an EU average ( 27 member states) of 6.5 $\mathrm{m}$, and a world average of just $4.3 \mathrm{~m}$ ! The Greek coastline accounts for roughly a third of the entire coastline of the Mediterranean, and to almost a quarter of that of the EU (27 member states) [11]. With over 70\% of Greece's population and over $90 \%$ of its tourists concentrated in its coastal zone, the possible consequences of climate change are likely to render this zone especially vulnerable to flooding and rising sea levels.

To facilitate a more systematic and all-inclusive image of the existing situation, we have employed a typology of coastal zone areas developed by the research group of the University of Thessaly in the context of the INTERREGUrbacost Programme (Co-ordinating agency: KEPEMEP-Med Regio: leader of the Greek consortium in which the University of Thessaly participated as main partner). The typology emerges from a classification / categorization which employs morphological features of natural and man-made space as criteria, including: a) The terrain (geomorphologic features, gradients etc.); b) vegetation (low, medium, high, ground cover, brush wood, bushes, trees); c) building construction (dense /sparse, unregulated); d) technical infrastructure (transportation, telecommunications, energy networks); e) excavations and earthworks (mining, quarrying, embankments, earth fills, land fills); f) country billboards. Also used as criteria are the uses and functions of the land, such as tourism, agricultural and the agrarian uses which are fundamental features of Greece's territorial capital and socio-economic reality / structure. Combining the above parameters (passed mainly on settlement and land use patterns) we produced the five types of coastal regions listed below:

1. Plains (flat terrains) with intensive cultivations and rural settlements, agritourism activities under development.

2. Flat areas with linear urban development-especially along the sea front having scattered building constructions (illegal or not). Dominant land uses: secondary residence and tourist accommodation. 
3. Rough terrains. Land cover: pastures, maquis vegetation, bush land, Traditional cultivations in terraces, rural settlements, agritourism activity under development.

4. Rough areas with linear urban development-especially along the sea fronthaving scattered building constructions (illegal or not). Dominant land uses: secondary residence and tourist accommodation.

5. Mountainous areas covered by forest vegetation or maquis, rough terrain, rocky coasts, low population density or empty, no human settlements, mountain tourism activities and isolated tourist installations (refuges, ski centers etc).

Recognizing, analyzing and interpreting the structural features of the coasts is an essential prerequisite for any institutional regulation and planning which seeks to bring about their viable and integrated protection and development.

A study of the brief history of spatial planning in Greece reveals that the regulation of coastal space (institutional instruments, planning techniques etc.) has mirrored the course of spatial planning in general, which, due to social, economic and technological developments, has moved from small - to largescale regulation. Thus, initial efforts sought to address the problems facing the coastline - meaning the coastal zone where water met land - with corresponding legislation (Law 2344/1940, later replaced by Law 2971/2001). Then, in the early 1980s, Law 1337/83 sought to tackle the problems of unregulated construction and access to the sea in a 500-metre coastal setback zone in which enclosures were forbidden. Finally, from the 1990s on, the focus has been on regulating the spatial organization of the coastal zone in general and on instituting new zones (in addition to those mentioned above) with a view to integrated coastal zone management, the removal of conflict between different land uses, free access to the sea and the regulation of pedestrian and vehicular traffic. The development of the core legislation (not including previsions from other legislation dealing indirectly with coastal zone) is summarized in Table 3.

Table 3: $\quad$ Core legislation relating to Greek coastal space.

\begin{tabular}{|c|c|c|}
\hline Date & Type and content of institutional regulation & Comments \\
\hline 1940 & $\begin{array}{c}\text { Compulsory Law 2344/1940 "On the Sea Shore (foreshore } \\
\text { and backshore)" }\end{array}$ & \\
\hline 1983 & $\begin{array}{c}\text { Law } 1337 / 83 \text { Articles } 23 \text { and } 24 \text { "On the protection of } \\
\text { coasts and coastal roads", OGG A33/83 }\end{array}$ & $\begin{array}{c}\text { Never } \\
\text { implemented }\end{array}$ \\
\hline 1984 & $\begin{array}{c}\text { Presidential Decree 236/84 “On enclosing coastal land”, } \\
\text { OGG 95/84 }\end{array}$ & $\begin{array}{c}\text { Never } \\
\text { implemented }\end{array}$ \\
\hline 2001 & $\begin{array}{c}\text { Law 2971/01 “On the Sea Shore (foreshore, backshore } \\
\text { etc.)", OGG A285/2001 }\end{array}$ & \\
\hline 2010 & $\begin{array}{c}\text { National Guidelines for the Spatial Planning and } \\
\text { Sustainable Development of the Coastal Zone - Ministerial } \\
\text { Decision }\end{array}$ & $\begin{array}{l}\text { Not yet } \\
\text { finalized }\end{array}$ \\
\hline
\end{tabular}

Source: Relevant issues of the Official Government Gazette (OGG), Hellenic Ministry for the Environment, Physical Planning and Public Works, 2009.

The coastal zones and the regulations applying to each will be examined in more detail below. 


\subsection{The sea shore: foreshore and backshore zones}

The foreshore (the 'amphibious' part of the coastal zone exposed at low tide) and the backshore are the most sensitive and critical coastal zone from an ecological and environmental as well as a social, economic and developmental point of view. The space of the foreshore is delimited by nature. According to the current legislation: "The foreshore is the zone which is wet by the largest nonextraordinary waves" (OGG A285/2001). In contrast, the backshore is a social product defined by the state ("The backshore is the terrestrial zone added to the foreshore which is defined as having a breadth of up to fifty (50) metres from the upper limit of the foreshore to serve communication between land and sea and vice versa"). As spatial zones, the foreshore and the backshore are organically and functionally linked. There can be no foreshore without a backshore, which is the functionally public space necessary for enjoying the environmental and social good of the foreshore and for providing free access to it.

Law 2344/1940, the first legislation that sought to regulate the foreshore and backshore zone, dates back to the end of the interwar period and was groundbreaking for its time. It would be amended on several occasions during what would prove a long active life (over 60 years), the most important amendment, from an environmental point of view-in view of the accelerated urbanization of the coastal zone during the post-war period (see the following subsection) being the institution of a new and larger backshore width (raised from 30 to 50 metres) in 1983. Clearly, this initial legislation could not foresee the developments to come in the contemporary period, which included tourist development, coastal erosion and a rise in sea-levels due to the greenhouse effect.

Still, the efforts which began in the early 1980s to thoroughly overhaul the special legislation relating to the foreshore were slow in bearing fruit, delaying the process excessively until the first decade of the 21 st century. And while the Hellenic Ministry of Finance sought to modernize the relevant institutional framework in technical, administrative and bureaucratic terms, despite the lastminute amendments, the new institutional framework ultimately proved unsuccessful both in ensuring the public good it was supposed to have defended, and in ushering in genuinely new conditions. For instance, the institutional protection provided for coastal zone could have been bolstered - as the circumstances of the age demanded, with the proliferation of building without planning permission - by legally setting the coastal setback at a minimum of 50 metres from the upper limit of the foreshore.

To be truly effective and beneficial, any legal framework governing the space, development and environment of the foreshore and backshore would have to take a contemporary and innovative approach to land policy issues. For instance, the provisions relating to the expropriation of property in the backshore zone would have to come packaged with the means (financial resources) for purchasing these properties. Otherwise, other land policy instruments will have to be found for acquiring the backshore land, which must, in accordance with the core aim expressed by the law itself, be both public and for common use. Moreover, on a 
larger scale, the zone must be spatially and geographically linked to the coastal zone as a whole - of which the strip comprised of the foreshore and backshore constitutes a spatial subset - to an adequate depth both landwards and seawards.

\subsection{0-metres coastal setback in which enclosures are forbidden}

Law 1337/83 on the expansion of cities and settlements, which formed the basis for the Urban Restructuring Programme (EPA), also included provisions relating to the protection of the rural environment, primarily through the institution of the Controlled Construction Zone and the 500-metre setback from the coast in which enclosures were forbidden, both to protect the coasts and to ensure access to them - a perennial issue in Greece. This second provision has proven of critical importance in protecting the coastal zone, even though it has not been applied as widely as expected, despite the importance of the issue for Greece and Greek public opinion being supposedly sensitive to the issue of 'liberating' the nation's coasts. These innovative and radical provisions addressed two issues as crucial in today's social context as they were then:

a) The exclusion - as the rule - of enclosures in a 500-metre setback zone from the shoreline intended to ensure free access to the sea; in those cases were enclosures were permitted, guidelines were provided for their positioning and construction in accordance with the use to which the enclosed land was to be put. It should be noted that the Presidential Decree was formulated and published with the application of this provision specifically in mind;

b) The creation (through the expropriation of privately-owned property for the public good) of public access routes to the sea and the shore. These routes are chiefly foreseen as pedestrian, without this precluding the creation of roads for vehicles with the required parking spaces but without provisions for roadside plot divisions and building constructions.

It should be noted that the law foresaw the demolition of existing enclosures blocking access to the coast - a radical measure by the standards of the time - as well as the removal of buildings on the shore and the transfer of the ownership of these buildings to the local authorities or to organizations for the public good until their demolition. However, while these provisions were considered reasonable by all parties and satisfied the 'sense of public justice', they have with very few exceptions - not been applied, due to the familiar inertia and involvement of the governmental bodies and the corruption and clientelism of local politics. However, this does not rob the provisions of their importance even today, since all remain in force and can be activated at any time, demonstrating once again that Greece has a wellstocked and well-provisioned - though inactive, unused and sometimes undermined - spatial planning armoury.

\subsection{Zones foreseen in the national guidelines on coastal areas}

The need for the coastal zone to be organized and administered in a more integrated way and on a larger scale in the context of the guidelines laid down in international and European treaties and conventions necessitated the drawing up 
of national guidelines on the basis of an institutional instrument foreseen by Law 2742/99: the Special Framework for Spatial Planning and Sustainable Development (SFSPSD). However, although drafting of the framework - which addressed Greece's coastal space and islands - began in the late 1990s and the result was presented in 2003 as emergency legislation on Greece's coastal and island space, it has yet to be implemented. The latest version of the Framework, which was submitted to the Ministry of the Environment for discussion in 2009, is substantially different from the original, due to developments in international and European-Mediterranean space, as well as to changes in Greek spatial planning policy.

Specifically, the Framework now adheres to European models in promoting Integrated Coastal Zone Management (ICZM), defining the coastal zone more broadly both landwards and seawards, and introducing a three-way division of the coastal area into critical, dynamic and other/transitional zones, all of which have a terrestrial as well as a marine section and are subject to different provisions with regard to permissible construction and land uses. The landward limits of the transitory zone extend as far as the administrative boundaries of coastal municipalities, though not beyond or further than the 600-metre index contour line (Figure 9). These zones constitute the hinterland of the foreshore zone, and are equally important for the functioning of the coastal ecosystem and for the production activities that take place there.

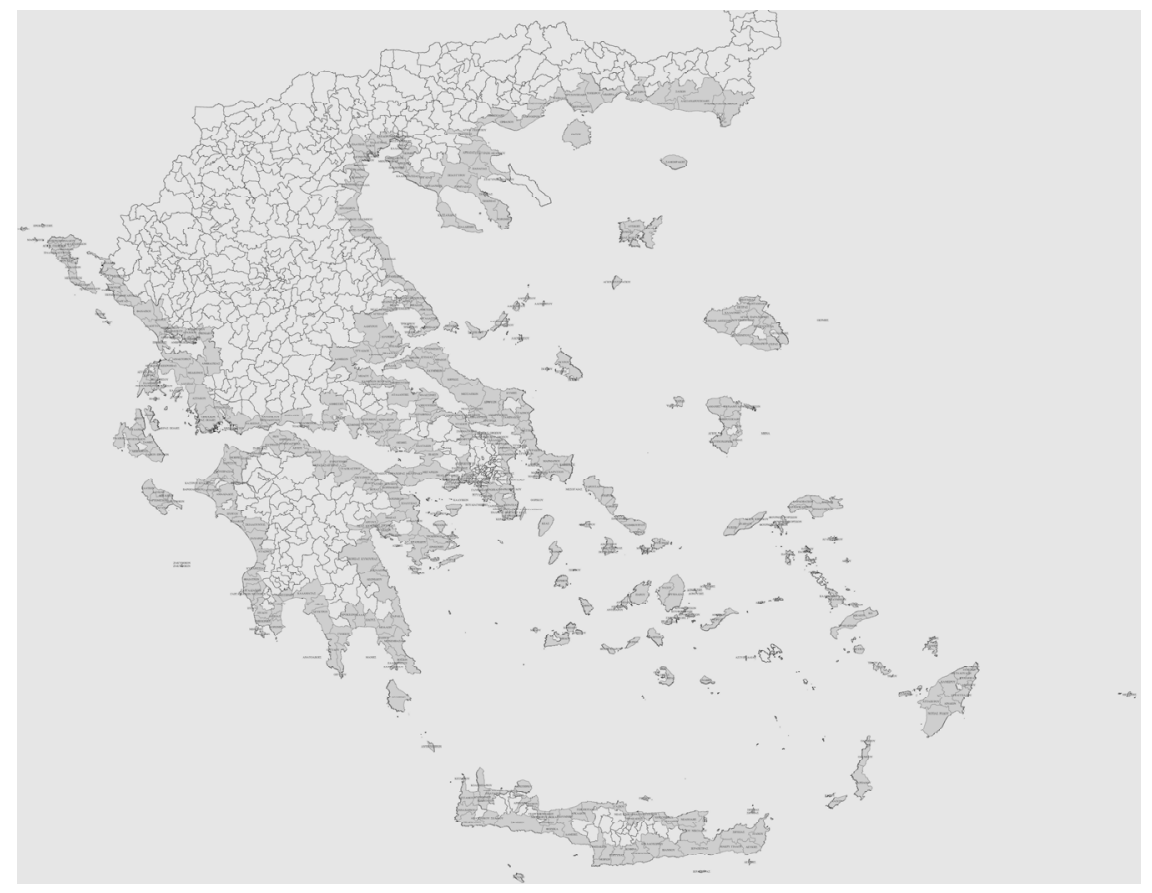

Figure 9: The coastal zone of Greece at the level of first-tier local authorities territorial units (marked in grey). 
Undoubtedly, the Special Framework (national guidelines) for coastal areas is both necessary and useful for planning, since it can coordinate and incorporate the existing regulations governing the foreshore and the 500-metre enclosurefree zone. Still, although it regulates construction in each coastal zone in detail, the Framework does not reference the aforementioned coastal legislation and correspondences cannot be drawn between the two. In addition, the framework does not seem to correlate satisfactorily either with the already approved Special Framework (national guidelines) on Tourism or with regional and local spatial plans.

However, quite apart from problems of internal cohesion and organization, the Framework seems to fail to address substantial issues relating to the degree of protection it provides for the coastal environment: its retention, for example, of a 50-metre setback from the shore for buildings in place of the 100-metre zone enforced in other countries, and its failure to ban roads running parallel to the coast, despite the pressure they exert for road-side constructions being extremely well-documented. It should be noted, too, that other Mediterranean countries (like Italy, Spain and Portugal) have introduced stricter provisions in relation to building on the coast (greater setbacks, stricter control of land uses etc.), while the Framework's provisions aimed at reducing the coverage coefficient in the dynamic zone in relation to the institutional framework for spatial planning in general remain somewhat ineffective.

\section{Conclusions}

In an era in which the greenhouse effect and desertification are making there presence felt ever more acutely as they pose a serious threat to the coastal and marine ecosystems in Greece and the Mediterranean, we need to look ahead to new organizational structures with a view to integrated planning for coastal regions. The 'usual' offices in the various ministries, regions, prefectures and municipalities that are usually called upon to solve the problems relating to demarcation, protection and administration are insufficient, as a result of which the all-important issues of coordination and cooperation between the bodies involved and the drafting and application of policy are totally ignored by the proposed regulations as they stand, which all fail to deal with the critical and important issues relating to the policy of creating a reserve of public land for the protection of the coastal environment.

To date, management by means of a powerful and inspired national programme - significantly absent from the post-war planning landscape - has not served to redress this state of affairs. With the experience amassed thus far and the requisite political will, the legal and technical solutions can be found to create free common spaces in the backshore zone, and to do so without burdening the public purse excessively. In the coastal zone, an area beset by problems of land ownership, it is essential that a special mechanism be put in place for their solution, meaning something similar to the French Conservatoire du littoral adapted to the Greek situation, which will help in the drafting of a well 
thought-out spatial planning policy for our coasts and provide the means for its application.

There is also an urgent need to incorporate/adapt/codify legislation relating to Spatial Planning in order to coordinate the activities and programmes of all the parties involved. The integrated coastal zone planning management remains a complex issue and a difficult project requiring systematic approach and data gathering. This will have to lead to the drawing up of a strategy which will be in accordance with and make active use of the favourable provisions included in the international conventions and EU guidelines as well as in the Blue Plan produced by the UN Mediterranean Action Plan to make it possible -within clearly limits to protect and develop a valuable natural resource of vast environmental and socio-economic importance.

\section{References}

[1] UNEP/MAP/Blue Plan (2005), Report on Environment and Development in the Mediterranean -RED

[2] Arnold, C. (2008), Mediterranean Islands, London: Survival Books

[3] Benoit, G. \& Comeau, A. (2005), Méditerranée: Les perspectives du Plan Bleu sur l'environnement et le developpement, Editions de l'Aube et Plan Bleu

[4] UNEP/MAP/PAP-RAC (2010), Protocol on ICZM in the Mediterranean. Available at: http://www.pap-thecoastcentre.org/about.php?blob_id $=56 \&$ lang=en

[5] UNEP/MAP/PAP-RAC (2001), Coastal Area Management Programme CAMP: Strategic Framework for the Future Priority Actions Programme RAC Split, May 2001. Available at: http://www.pap-thecoastcentre.org/

[6] DATAR (2004), Construire ensemble un developpement equilibre du littoral, Rapport sous la direction de Christine Bouyer, Paris: La Documentation Française

[7] European Commission (2000a), Recommendation on the implementation of the Integrated Coastal Zone Management, Brussels: COM2000/545

[8] European Commission (2000b), Communication of the Commission on the Integrated Coastal Zone Management. A Strategy for Europe Brussels : COM 2000/547

[9] European Union - Council (2002), Recommendation of The European parliament and the Council on the implementation of the Integrated Coastal Zone Management, Brussels: Official Journal of the European Communities 2002/413, L148/6-6-2002

[10] European Commission (2007), Communication of the Commission. Evaluation Report on the Integrated Coastal Zone Management in Europe. Brussels: COM 2007/308

[11] Karyotis, T. (2010) "The Aegean and the European Union", Journal Epikaira available at http://m-epikaira.gr/category/diethni/ 